\title{
Permanent Molar Trait Expression in the Late Neolithic Cave Burials of the Meuse Basin, Belgium
}

\author{
Frank L'Engle Williams ${ }^{1 *}$ and Rebecca L. George ${ }^{2}$ \\ ${ }^{1}$ Georgia State University \\ 2 University of Nevada, Reno
}

Keywords: Hastière Caverne M, Hastière Trou Garçon C, Sclaigneaux, Bois Madame, Maurenne Caverne de la Cave

\begin{abstract}
At least 250 cave burials along the Meuse river basin of Belgium yield prehistoric remains, and most date from the Late Neolithic period. Several of these collective burials have been radiocarbon dated, including the early/late Neolithic deposits of Hastière Caverne M and Hastière Trou Garçon C and the final/late Neolithic caves of Sclaigneaux and Bois Madame. An additional cave burial, Maurenne Caverne de la Cave, has been radiocarbon dated to the Middle Neolithic and final/late Neolithic periods, circa 4,635 to 3,830 years BP, which encompasses the entire range of dates for the other collective burials. Individuals $(n=127)$ are represented by fragmentary gnathic remains with in situ dental elements. Although the remains have been studied in detail, researchers have yet to compare dental morphology across cave sites. Arizona State University Dental Anthropology System (ASUDAS) scores of permanent molar morphology are employed to examine whether differences within and between the cave burials exist, and whether chronology and geography can account for the variation in traits. Affirming our expectations, the final/late Neolithic cave of Sclaigneaux, the most geographically distant cave burial, and secondarily Hastière Caverne $\mathrm{M}$, possibly the earliest site, emerge as the most distinctive. The final/late Neolithic sites of Sclaigneaux and Bois Madame exhibit the greatest variability of trait expression. This research contributes to the understanding of the relatedness of early farming communities, and these findings bear on the mobility and continuity of human groups in the Meuse basin of Belgium during the terminus of the Neolithic before the onset of the Bronze Age in northern Europe.
\end{abstract}

The Meuse River basin of central Belgium extends along a semi-continuous karstic uplift featuring numerous cliff walls, rock formations and at least 3,000 caverns. More than 250 of these caves preserve the remains of prehistoric humans. Although these caves have been known for centuries, formal exploration of the sites commenced in the winter of 1829-1830 and has continued to the present (Polet, 2011). Close to 200 of these funerary sites have been radiocarbon dated to the Late Neolithic period (Toussaint et al., 2001). Many of these are collective burials and contain five to 15 individuals (Polet, 2011), however, some are larger, such as the caves of Bois Madame and Sclaigneaux (Dumbruch, 2003; De Paep \& Polet, 2007). Only eight percent of these funerary sites contain between 55 and 60 individuals (Polet, 2011).

Hundreds of skeletal fragments and dental elements have been investigated from Hastière Caverne M (Hastière M), Hastière Trou Garçon C
(Trou Garçon), Sclaigneaux, Bois Madame and Maurenne Caverne de la Cave (Maurenne) (Figure $1)$, and adults of both sexes and children are represented, suggesting familial, kin or descent groups used the caves for burial. These five cave deposits are all radiocarbon dated to the Late Neolithic (Table 1). However, Maurenne is associated with three dates from the terminus of the Late Neolithic $(4,160 \pm 45 ; 3,950 \pm 70 ; 3,830 \pm 90$ years BP), and one date, $4,635 \pm 45$ years BP, from the Middle Neolith-

*Correspondence to:

Frank L'Engle Williams

Department of Anthropology

Georgia State University

P.O. Box 3998

Atlanta, GA, 30302-3998

United States

frankwilliams@gsu.edu 


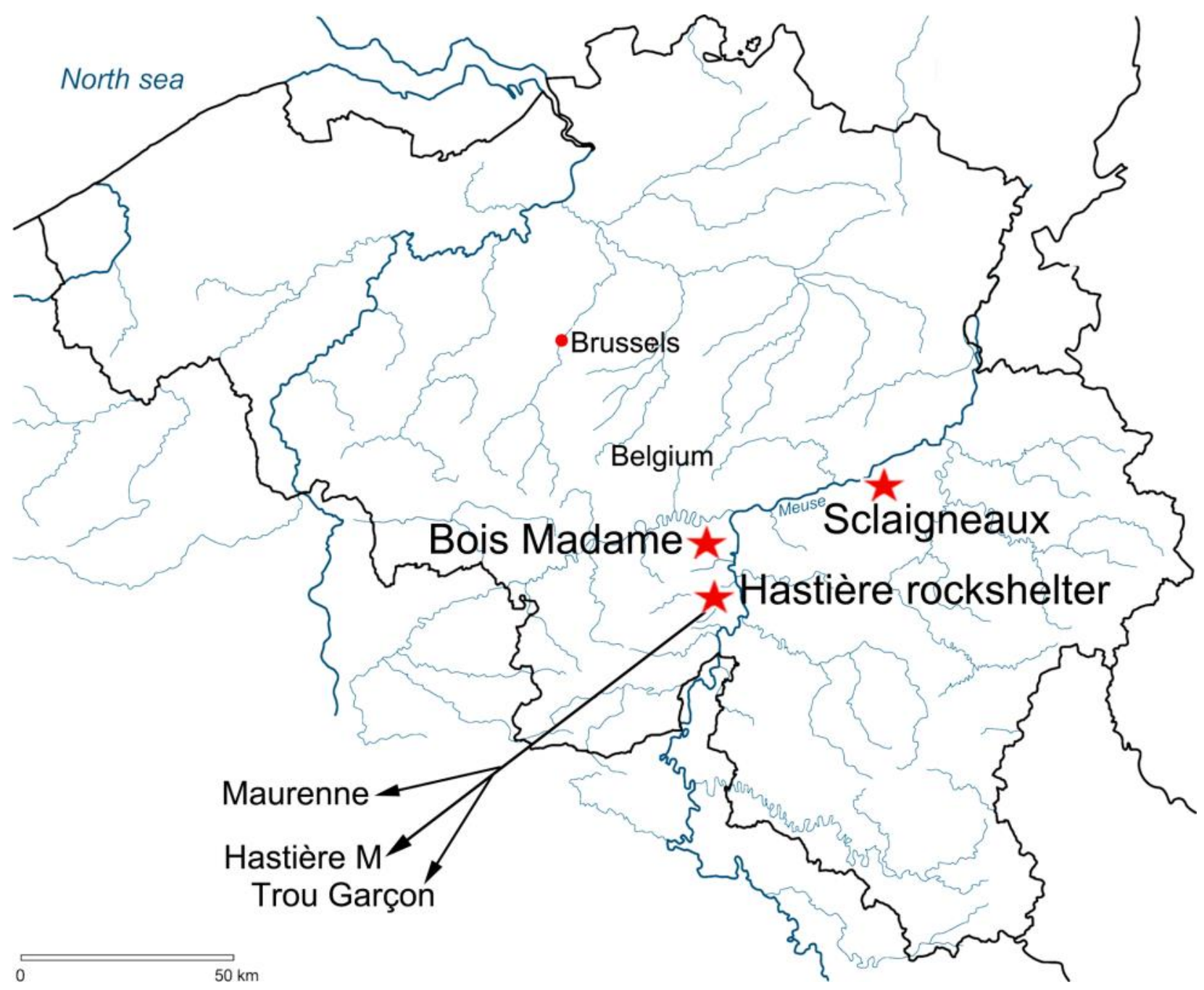

Figure 1. Map of Belgium showing the location of five Late Neolithic collective burials along the Meuse River system.

Table 1. Radiocarbon dates associated with five Neolithic collective burials of Belgium, arranged by site and by distance from Hastière rockshelter; dating was conducted using Accelerated Mass Spectrometry (AMS) at Oxford University, UK (OxA) and the University of Groningen (GrA), and conventional methods at the University of Louvain, Belgium (Lv).

\begin{tabular}{cccc}
\hline Collective burial & Sample number & Dates in years BP & Reference \\
\hline Hastière M & AMS OxA-6558 & $4,345 \pm 60^{a}$ & Bronk-Ramsey et al. (2002) \\
Trou Garçon & AMS OxA-6853 & $4,220 \pm 45^{\mathrm{a}}$ & Bronk-Ramsey et al. (2002) \\
Maurenne & AMS OxA-9025 & $4,635 \pm 45^{\mathrm{b}}$ & Bronk-Ramsey et al. (2002) \\
Maurenne & AMS OxA-9026 & $4,160 \pm 45^{c}$ & Bronk-Ramsey et al. (2002) \\
Maurenne & Lv-1483 & $3,950 \pm 70^{c}$ & Toussaint (2007) \\
Maurenne & Lv-1482 & $3,830 \pm 90^{c}$ & Toussaint (2007) \\
Bois Madame & AMS OxA 10831 & $4,075 \pm 38^{c}$ & Dumbruch (2003) \\
Bois Madame & AMS OxA 10830 & $3,910 \pm 40^{c}$ & Dumbruch (2003) \\
Sclaigneaux & GrA-32975 & $4,155 \pm 35^{c}$ & De Paepe \& Polet (2007) \\
\hline
\end{tabular}

${ }^{a}$ early/late Neolithic; ${ }^{b}$ Middle Neolithic; ${ }^{c}$ final/late Neolithic 
ic, implying its use for more than 800 years

(Vanderveken, 1997; Bronk-Ramsey et al., 2002;

Toussaint, 2007).

The Maurenne burial is adjacent to Hastière rockshelter formation (see Figure 1). Two other collective burials at this site include Hastière $M$ and Trou Garçon. Hastière $M$ is one of the oldest Late Neolithic cave sites and dates to $4,345 \pm 60$ years BP, followed by Trou Garçon, which has yielded a date of 4,220 \pm 45 years BP (BronkRamsey et al., 2002; Toussaint, 2007). These two can be described as early/late Neolithic.

Two large, well-studied final/late Neolithic cave burials are Sclaigneaux and Bois Madame. Sclaigneaux is associated with a single radiocarbon date of 4,155 \pm 35 years BP (De Paepe, 2007; De Paepe \& Polet 2007). At Bois Madame in the Burnot Valley, two dates have been obtained. Both of these derive from the boundary of the fourth millennium prior to the Bronze Age, 4,075 \pm 38 years BP and $3,910 \pm 40$ years $\mathrm{BP}$, suggesting the collective burial of Bois Madame may have been utilized for more than 150 years (Bronk-Ramsey et al., 2002; Dumbruch, 2003, 2007).

\section{Funerary context}

Given the scarcity of habitation sites, these prehistoric peoples are primarily known from their remains in funerary caves and rockshelters. A range of burial practices has been inferred, including cremation, burial, a simple deposition of individuals on cave floors and cu-marks with flint implements. Comingled remains comprise a majority of the funerary deposits (Toussaint et al., 2001; Toussaint, 2007; Polet, 2011). At some caves, such as Bois Madame, the bones are found in a haphazard order as if the individuals were left unburied and later disturbed by human or non-anthropogenic agents (Dumbruch, 2003). The mixture of individuals within these collective burials could have arisen from bioturbation. However, the deliberate movement, occasional regrouping and comingling of bodies is more likely to be the result of burial rites, reburial and/or adding additional individuals (Toussaint et al., 2001; Toussaint, 2007).

\section{Comparing individuals across cave burials}

Although several well-preserved Late Neolithic crania are present, most individuals are represented by fragmentary gnathic remains with associated molars in situ, permitting an investigation of variation within and between sites in nonmetric dental trait expression using the Arizona State University Dental Anthropology System (ASUDAS) (Turner et al., 1991; Scott and Irish, 2017). Prior studies of the inhabitants of these Late Neolithic caves have found a lack of differentiation in diet (Garcia Martín, 1999; Semal et al., 1999), internment behavior (Vanderveken, 1997; Toussaint et al., 2001, 2003) and stature was estimated to be largely unimodal (Orban et al., 2000). However, chronological distinctions are apparent from radiocarbon dating. On the basis of chronology, we expect the early/late Neolithic sites to be more similar to each other in dental morphological expression than to the final/ late cave burials, and vice versa. The three final/ late Neolithic dates from Maurenne suggest this collective burial is more likely to resemble later sites than earlier ones.

It is also possible that differences in dental morphology will be patterned with respect to geography. Based on distance, individuals from Hastière rockshelter (Hastière $\mathrm{M}$ and Trou Garçon) and Maurenne should be more similar to one another, and secondarily to Bois Madame, whereas Sclaigneaux should be the most distinctive (see Figure 1).

\section{Materials and Methods}

A total of 127 individuals from the five caves were examined (Vanderveken, 1997; Toussaint et al.,

Table 2. Neolithic samples by cave, element, and number of individuals.

\begin{tabular}{cccc}
\hline Neolithic cave site & Maxillae & Mandibles & Total \\
\hline Hastière M & 10 & 10 & 20 \\
Trou Garçon & 6 & 1 & 7 \\
Maurenne & 9 & 21 & 30 \\
Bois Madame & 13 & 15 & 28 \\
Sclaigneaux & 12 & 30 & 42 \\
\hline Total & 50 & 77 & 127 \\
\hline
\end{tabular}


2001; Dumbruch, 2003; De Paep, 2007; Toussaint, 2007; Williams and Polet, 2017; Table 2). Gnathic fragments were chosen on the basis of completeness and only relatively unworn crowns were examined. No isolated teeth were included to avoid errors in attribution. Given the lack of anterior teeth preserved in situ, and the inconsistent preservation of premolars, only molars were observed. Preference was given to young adults and subadults with relatively unworn cusps of permanent molars to increase the likelihood of accurate scoring, and included Smith (1984) wear stages 1 to 4. Individuals who exhibited substantial attrition, exceeding stage 4 (Smith, 1984), were excluded from the analysis (Turner et al., 1991; Scott and Irish, 2017).

\section{Dental cast preparation}

Dental casts were created from dental impressions of the original Neolithic material housed at the Royal Belgian Institute of Natural Sciences in Brussels. To create the dental molds, the dentition was cleaned and a thin layer of dental molding material, polyvinylsiloxane (President Jet Plus Regular Body, Coltène-Whaledent) was applied to the occlusal surface of the molars and allowed to air dry. Dental casts were created at Georgia State University by pouring centrifuged epoxy resin and hardener (Buehler) onto the dental impressions, which were placed into putty crucibles - stabilized with hardener (Buehler) - to catch the excess mixture. The casts dried for 24 hours before extraction.

\section{Analysis}

Dental morphology has been shown to be highly heritable (Turner et al., 1991; Scott and Turner, 1997; Irish, 2006; Hanihara, 2008; Scott and Irish, 2017; Scott et al., 2018). Dental casts, supplemented with photographic images, were scored by a single observer (RLG) to avoid issues of interobserver error (Turner and Scott, 1997; Hardin and Legge, 2013). Previously conducted intraobserver error analyses on 34 dental morphological traits found trait agreement at levels of 0.621 or above (McHugh, 2012). Since single-sided gnathic fragments were available for the great majority of the individuals, dental antimeres could not be examined to identify the maximum expression of any trait. It is possible that some of the maxillary and mandibular fragments belonged to the same individuals. However, given the preservation of the remains, pairing these elements was not possible. If some elements are indeed associated, then the total sample size of 127 would be smaller. Since 77 man- dibular and 50 maxillary fragments are included, a potential minimum number of individuals (MNI) is 77 (Table 2). These associations are likely irrelevant in the current study as maxillary and mandibular molar traits are discussed separately

Another potential problem from the lack of matching elements might have arisen from inadvertently scoring antimeres from the same individual. However, this is unlikely for several reasons. First, only in situ molars rather than isolated elements were scored. Second, the range of dental attrition and dental ages suggests each gnathic fragment can be considered unique. Therefore, each fragment was treated as an individual (Hardin and Legge, 2013) as shown in Table 2, and the dental morphological traits were discussed independently. Score frequencies for each trait with respect to each cave site were calculated. Statistical analyses were not attempted due to the small and idiosyncratic sample sizes.

\section{Results}

All scores ascribed to individuals are presented in the context of the ASUDAS.

\section{Maxillary molars}

Metacone

For $\mathrm{M}^{1}$, individuals from Hastière $\mathrm{M}$ and Trou Garçon often exhibit a metacone with a score of 4 (see Table 3). Fewer individuals have a larger metacone with a score of 5 . In contrast, individuals from Maurenne and Bois Madame frequently present a metacone with a score of 5 and have a lower frequency of individuals with a score of 4 .

Sclaigneaux shows an equal prevalence of individuals with metacone scores of 4 and 5 .

For the second molar $\left(\mathrm{M}^{2}\right)$, the dominant pattern across sites is a score of 3 or 4 , though there is some variation in expression (Table 3 ). For instance, Hastière $M$ and Trou Garçon are nearly divided equally between these two scores, whereas the final/late Neolithic burials present a greater tendency for a metacone with a score of 4 . Individuals from Bois Madame show a greater range of expression in their metacone scores as they range from 2 to 5.

Although the sample size for $\mathrm{M}^{3}$ is limited, the individual from Hastière $\mathrm{M}$ has a large metacone with a score of 5, whereas individuals from both Maurenne and Bois Madame exhibit a smaller cusp and have scores of 3 . The other two sites are intermediate and have scores of 4 for the $\mathrm{M}^{3}$ metacone (Table 3). 
Table 3. Frequencies of maxillary traits.

\begin{tabular}{|c|c|c|c|c|c|c|c|c|c|c|}
\hline \multirow[b]{2}{*}{ Site } & \multirow[b]{2}{*}{$n$} & \multirow[b]{2}{*}{ Trait \& Tooth } & \multicolumn{8}{|c|}{ Frequency of score } \\
\hline & & & 0 & 1 & 2 & 3 & 4 & 5 & 6 & 7 \\
\hline Hastière $\mathrm{M}$ & 8 & \multirow{5}{*}{$\begin{array}{l}\text { Metacone } \\
\left(\mathrm{M}^{1}\right)\end{array}$} & & & & & 0.875 & 0.125 & & \\
\hline Trou Garçon & 5 & & & & & & 0.800 & 0.200 & & \\
\hline Sclaigneaux & 10 & & & & & & 0.500 & 0.500 & & \\
\hline Maurenne & 8 & & & & & & 0.250 & 0.750 & & \\
\hline Bois Madame & 11 & & & & & & 0.273 & 0.727 & & \\
\hline Hastière $\mathrm{M}$ & 5 & \multirow{5}{*}{$\begin{array}{l}\text { Metacone } \\
\left(\mathrm{M}^{2}\right)\end{array}$} & & & & 0.600 & 0.400 & & & \\
\hline Trou Garçon & 4 & & & & & 0.500 & 0.500 & & & \\
\hline Sclaigneaux & 6 & & & & & 0.167 & 0.833 & & & \\
\hline Maurenne & 3 & & & & & 0.333 & 0.667 & & & \\
\hline Bois Madame & 8 & & & & 0.125 & 0.125 & 0.375 & 0.375 & & \\
\hline Hastière M & 1 & \multirow{5}{*}{$\begin{array}{l}\text { Metacone } \\
\left(\mathrm{M}^{3}\right)\end{array}$} & & & & & & 1.000 & & \\
\hline Trou Garçon & 2 & & & & & 0.500 & 0.500 & & & \\
\hline Sclaigneaux & 3 & & & & & 0.333 & 0.667 & & & \\
\hline Maurenne & 1 & & & & & 1.000 & & & & \\
\hline Bois Madame & 2 & & & & & 1.000 & & & & \\
\hline Hastière M & 7 & \multirow{5}{*}{$\begin{array}{l}\text { Hypocone } \\
\left(\mathrm{M}^{1}\right)\end{array}$} & & & & & 0.429 & 0.571 & & \\
\hline Trou Garçon & 4 & & & & & & 0.500 & 0.500 & & \\
\hline Sclaigneaux & 10 & & & & & & 0.400 & 0.600 & & \\
\hline Maurenne & 8 & & & & & & 0.125 & 0.875 & & \\
\hline Bois Madame & 11 & & & & & 0.273 & 0.364 & 0.364 & & \\
\hline Hastière $\mathrm{M}$ & 6 & \multirow{5}{*}{$\begin{array}{c}\text { Hypocone } \\
\left(\mathrm{M}^{2}\right)\end{array}$} & & & 0.167 & 0.667 & 0.167 & & & \\
\hline Trou Garçon & 2 & & & & & 1.000 & & & & \\
\hline Sclaigneaux & 4 & & & & & 0.500 & 0.500 & & & \\
\hline Maurenne & 3 & & & & 0.333 & & 0.667 & & & \\
\hline Bois Madame & 8 & & & & 0.125 & 0.750 & 0.125 & & & \\
\hline Hastière M & 1 & \multirow{5}{*}{$\begin{array}{c}\text { Hypocone } \\
\left(\mathrm{M}^{3}\right)\end{array}$} & & & & 1.000 & & & & \\
\hline Trou Garçon & 1 & & & & & & 1.000 & & & \\
\hline Sclaigneaux & 3 & & 0.333 & & 0.333 & 0.333 & & & & \\
\hline Maurenne & 4 & & & & & & 1.000 & & & \\
\hline Bois Madame & 2 & & & 0.500 & & 0.500 & & & & \\
\hline Hastière $\mathrm{M}$ & 5 & \multirow{5}{*}{$\begin{array}{c}\text { Metaconule } \\
\left(\mathrm{M}^{1}\right)\end{array}$} & 0.800 & & 0.200 & & & & & \\
\hline Trou Garçon & 3 & & 0.667 & & 0.333 & & & & & \\
\hline Sclaigneaux & 8 & & 1.000 & & & & & & & \\
\hline Maurenne & 6 & & 0.833 & 0.167 & & & & & & \\
\hline Bois Madame & 9 & & 0.667 & & 0.333 & & & & & \\
\hline Hastière M & 8 & & 0.500 & 0.250 & 0.125 & 0.125 & & & & \\
\hline Trou Garçon & 4 & & 0.500 & 0.250 & 0.250 & & & & & \\
\hline Sclaigneaux & 4 & $\begin{array}{l}\text { Metaconule } \\
\left(\mathrm{M}^{2}\right)\end{array}$ & 1.000 & & & & & & & \\
\hline Maurenne & 2 & & 0.500 & 0.500 & & & & & & \\
\hline Bois Madame & 7 & & 0.714 & 0.286 & & & & & & \\
\hline Hastière M & 1 & & 1.000 & & & & & & & \\
\hline Trou Garçon & 2 & & 0.500 & & & & 0.500 & & & \\
\hline Sclaigneaux & 2 & Metaconule & 1.000 & & & & & & & \\
\hline Maurenne & 1 & & 1.000 & & & & & & & \\
\hline Bois Madame & 2 & & 0.500 & 0.500 & & & & & & \\
\hline Hastière M & 3 & & 0.333 & 0.667 & & & & & & \\
\hline Trou Garçon & 2 & & 0.500 & 0.500 & & & & & & \\
\hline Sclaigneaux & 3 & Carabelli's Trait & 0.333 & & & & & 0.333 & 0.333 & \\
\hline Maurenne & 2 & & 1.000 & & & & & & & \\
\hline Bois Madame & 5 & & & & 0.200 & 0.200 & 0.200 & 0.200 & & 0.200 \\
\hline Hastière M & 3 & & 1.000 & & & & & & & \\
\hline Trou Garçon & 1 & & 1.000 & & & & & & & \\
\hline Sclaigneaux & 2 & Carabelli's Trait & & 0.500 & & 0.500 & & & & \\
\hline Maurenne & 3 & $\left(\mathrm{M}^{2}\right)$ & 1.000 & & & & & & & \\
\hline Bois Madame & 2 & & & & 0.500 & 0.500 & & & & \\
\hline Hastière M & 4 & & 1.000 & & & & & & & \\
\hline Trou Garçon & 3 & & 1.000 & & & & & & & \\
\hline Sclaigneaux & 3 & Parastyle & 0.667 & & & 0.333 & & & & \\
\hline Maurenne & 2 & & 1.000 & & & & & & & \\
\hline Bois Madame & 8 & & 1.000 & & & & & & & \\
\hline Hastière M & 5 & & 1.000 & & & & & & & \\
\hline Trou Garçon & 3 & Parastyle & 0.667 & 0.333 & & & & & & \\
\hline Sclaigneaux & 4 & $\left(\mathrm{M}^{2}\right)$ & 0.750 & & 0.250 & & & & & \\
\hline Bois Madame & 7 & & 1.000 & & & & & & & \\
\hline
\end{tabular}


Hypocone

The $\mathrm{M}^{1}$ hypocone is primarily scored as a 4 or 5 nearly evenly across three of the sites (see Table 3). Most individuals from Maurenne, though, are scored as 5 and more than a quarter of the $\mathrm{M}^{1}$ samples from Bois Madame (27.3\%) exhibit a smaller hypocone and are characterized by scores of 3 .

For $\mathrm{M}^{2}$, the hypocone tends to be expressed most strongly at Maurenne and Sclaigneaux as most individuals at these sites have scores of 4 . For Bois Madame and Hastière $\mathrm{M}$, a smaller hypocone with a score of 3 is the most frequent expression, with considerable variation (see able 3 ).

The $\mathrm{M}^{3}$ hypocone is variably expressed at Sclaigneaux and Bois Madame. In comparison, the $\mathrm{M}^{3}$ hypocone is most frequently larger at Trou Garçon and Maurenne with scores of 4 (see Table 3).

Metaconule (Cusp 5)

The metaconule is absent at Sclaigneaux across the molars (see Table 3). This is not the case at the other sites with the exception of $\mathrm{M}^{3}$ in which individuals from Hastière $M$ and Maurenne also lack Cusp 5. For $\mathrm{M}^{1}$, three individuals from Bois Madame present small metaconules with a score of 2 . The early/late Neolithic cave burials of Hastière $M$ and Trou Garçon both exhibit substantial variation in the expression of the metaconule across the molars (see Table 3). Variation at the early/late Neolithic sites is particularly marked for the $\mathrm{M}^{2}$ at Hastière $M$ where the expression of Cusp 5 ranges from absent in half of the individuals to moderately expressed with scores of 1-3 in the other half. Trou Garçon is mostly associated with scores of 1 and 2. Maurenne and Bois Madame are similar in their low to absent expression of the metaconule on $\mathrm{M}^{2}$ and $\mathrm{M}^{3}$ (Table 3). In contrast, a prominent metaconule is expressed on the $\mathrm{M}^{3}$ of Hastière $\mathrm{M} 29$, presenting a score of 5 (Figure 2).

Carabelli's trait

Carabelli's trait is relatively well represented across these Neolithic sites on $\mathrm{M}^{1}$ and $\mathrm{M}^{2}$ but is absent entirely on $\mathrm{M}^{3}$ (see Table 3). However, there is considerable variation within and between burials (Figures 3 and 4). For M11, Bois Madame exhibits the strongest expression of this trait, with one individual having a prominent Carabelli's cusp with a score of 7. Bois Madame present the greatest degree of variation, with expressions ranging from 25. One individual from Sclaigneaux has a large Carabelli's trait with a score of 5 and another is even larger with a score of 6 (Figure 4). In comparison, this trait on $\mathrm{M}^{1}$ is expressed as a 1 or absent altogether at the early/late Neolithic sites of Hastière $\mathrm{M}$ and Trou Garçon (see Table 3).

For $\mathrm{M}^{2}$, Hastière $\mathrm{M}$ and Trou Garçon $\mathrm{C}$ lack expressions of Carabelli's trait while the final/late sites of Sclaigneaux and Bois Madame show substantial variation ranging from scores 1-3 (see Table 3). Maurenne resembles the Hastière $M$ and Trou Garçon, in lacking evidence of a Carabelli's trait on $\mathrm{M}^{2}$ (see Table 3).

\section{Parastyle}

As at other locations worldwide (Scott et al. 2018), the expression of a parastyle is rarely observed in these Neolithic collective burials and is completely absent on $\mathrm{M}^{3}$ (see Table 3). However, a large $\mathrm{M}^{1}$ parastyle is scored as a 3 on Sclaigneaux 119. A smaller $\mathrm{M}^{2}$ parastyle is scored as a 2 on Sclaigneaux 99. In addition, a limited expression of a parastyle is noted for one $\mathrm{M}^{2}$ from Trou Garçon (I.G. 3873) characterized as a buccal pit (score of 1).

\section{Mandibular molars}

Anterior fovea

The anterior fovea on $\mathrm{M}_{1}$ is most frequently expressed as a score of 1 across the cave burials when it is present (Table 4; Figure 5). There is one individual, Maurenne 92, who presents a larger anterior fovea with a score of 3 .

\section{Groove pattern}

The groove pattern for $M_{1}$ is primarily the $Y$ pattern, with the exception of one individual from Hastière $\mathrm{M}$ and another from Sclaigneaux that exhibit an $X$ pattern. The near ubiquity of the $Y$ pattern, particularly at the final/late Neolithic cave burials, is further evidenced by the relatively large number of individuals with this configuration. This includes all of the Maurenne $(n=12)$ and Bois Madame $(n=8)$ assemblages, and nine out of 10 individuals from Sclaigneaux (see Table 4).

The groove patterns for $\mathrm{M}_{2}$ and $\mathrm{M}_{3}$ are more variable (see Table 4). For $\mathrm{M}_{2}$, the groove pattern for the early/late Neolithic cave burial of Trou Garçon presents as an X. Individuals from Hastière $M$ most often exhibit the plus groove pattern with some expression of the $Y$ pattern. At Maurenne, all three groove pattern variants are evident (see Table 4). For $M_{3}$, Hastière $M 10$ exhibits an $X$ groove pattern, as do most individuals from Maurenne.

The final/late Neolithic sites exhibit more variability in groove patterning for both $\mathrm{M}_{2}$ and $\mathrm{M}_{3}$ than is observed for these teeth in the earlier cave burials. All three configurations are visible at Sclaigneaux, although the $Y$ pattern is the least 


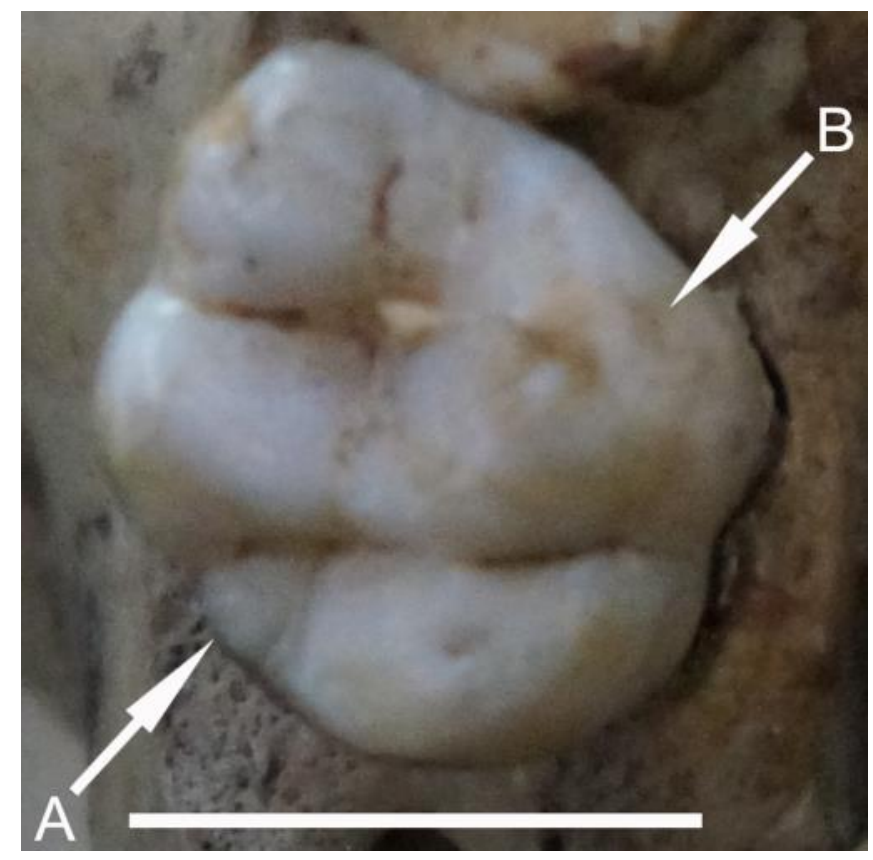

Figure 2. Hastière Trou Garçon $C 20 Z$, a right $\mathrm{M}^{1}$ shows (a) a large metaconule or Cusp 5 (ASUDAS score $=2$ ) and $(b)$ a pit form of Carabelli's trait (ASUDAS score $=$ 1 ); scale bar $=1 \mathrm{~cm}$.

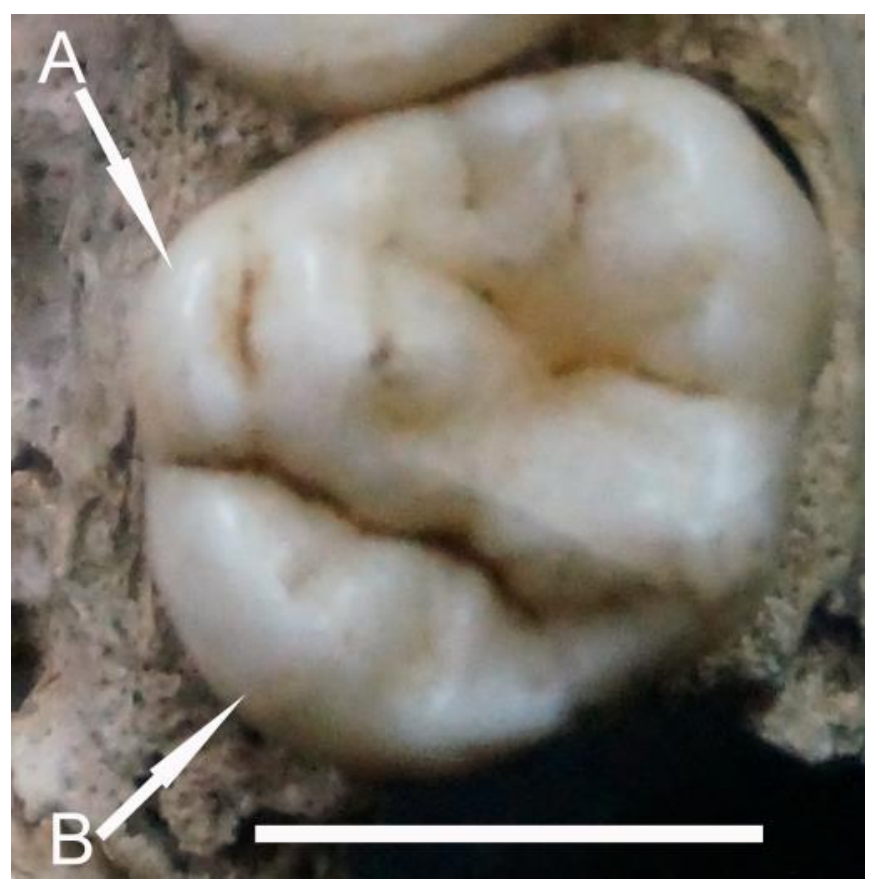

Figure 4. Sclaigneaux 119, a left $\mathrm{M}^{1}$, exhibits (a) a pronounced Carabelli's cusp (ASUDAS score $=6$ ), and $(b)$ a large metacone (ASUDAS score $=4$ ); scale bar $=1 \mathrm{~cm}$.

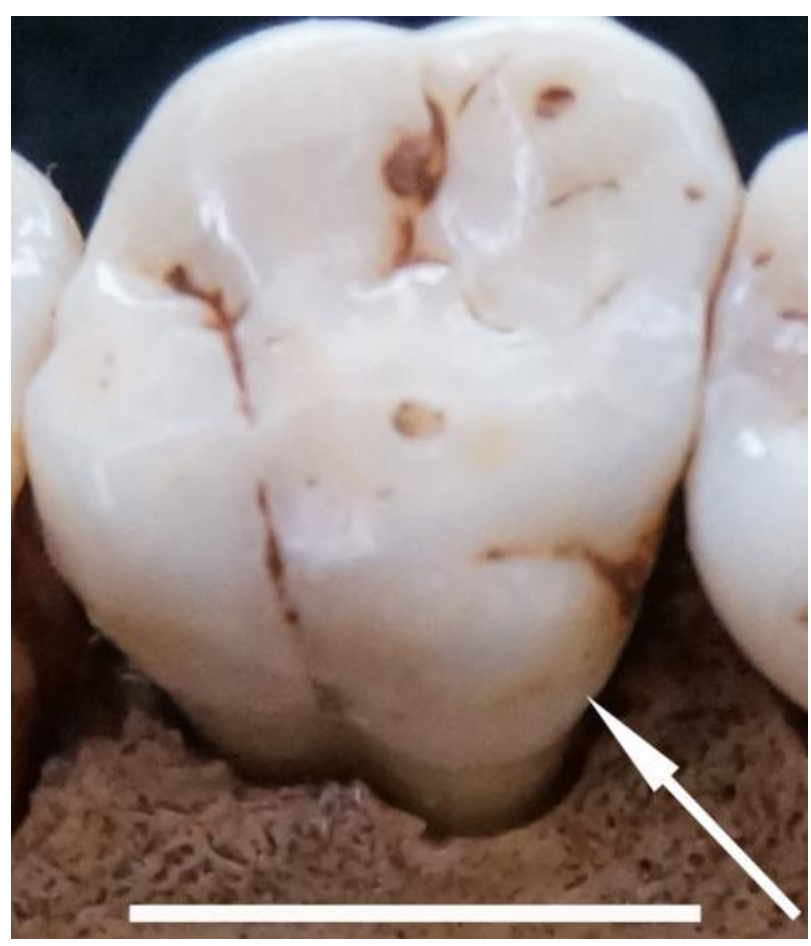

Figure 3. Bois Madame, BM Mx 11, a right maxillary fragment, demonstrates a large Carabelli's trait (ASUDAS score $=7$ ), identified by a white arrow on $\mathrm{M}^{1}$; scale bar $=1 \mathrm{~cm}$.

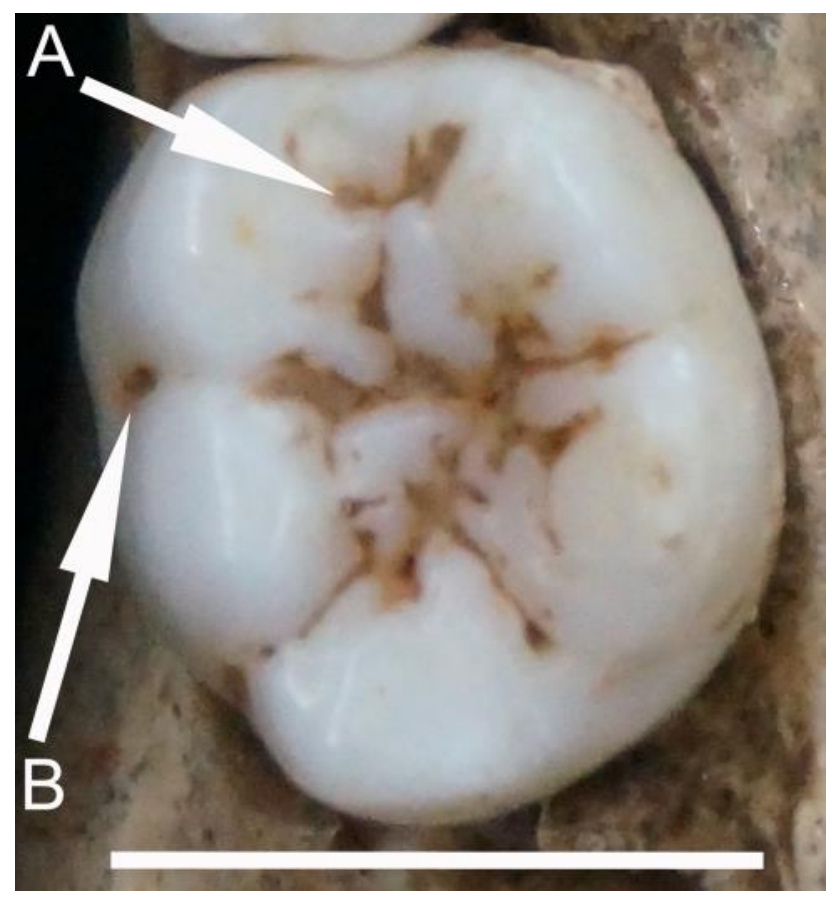

Figure 5. Bois Madame BM Md 32, a left $\mathrm{M}_{1}$, shows (a) an anterior fovea (ASUDAS score $=1$ ) and $(b)$ a protostylid (ASUDAS score $=1$ ), both of which are commonly found across cave sites; scale bar $=1$ $\mathrm{cm}$. 
Table 4. Frequencies of mandibular traits.

\begin{tabular}{|c|c|c|c|c|c|c|c|c|c|c|c|c|}
\hline \multirow[b]{2}{*}{ Site } & \multirow[b]{2}{*}{$n$} & \multirow[b]{2}{*}{ Trait \& tooth } & \multicolumn{10}{|c|}{ Frequency of score } \\
\hline & & & 0 & 1 & 2 & 3 & 4 & 5 & 6 & $x$ & $\mathbf{Y}$ & + \\
\hline Hastière M & 2 & \multirow{4}{*}{$\begin{array}{l}\text { Anterior } \\
\text { Fovea } \\
\left(\mathrm{M}_{1}\right)\end{array}$} & & 1.000 & & & & & & & & \\
\hline Sclaigneaux & 4 & & 0.750 & 0.250 & & & & & & & & \\
\hline Maurenne & 8 & & 0.625 & 0.250 & & 0.125 & & & & & & \\
\hline Bois Madame & 4 & & 0.500 & 0.500 & & & & & & & & \\
\hline Hastière M & 1 & & & & & & & & & 1.000 & & \\
\hline Sclaigneaux & 10 & Groove & & & & & & & & 0.100 & 0.900 & \\
\hline Maurenne & 12 & Pattern & & & & & & & & & 1.000 & \\
\hline Bois Madame & 8 & & & & & & & & & & 1.000 & \\
\hline Hastière M & 4 & & & & & & & & & & 0.250 & 0.750 \\
\hline Trou Garçon & 1 & Groove & & & & & & & & 1.000 & & \\
\hline Sclaigneaux & 15 & Pattern & & & & & & & & 0.400 & 0.067 & 0.533 \\
\hline Maurenne & 7 & $\left(\mathrm{M}_{2}\right)$ & & & & & & & & 0.143 & 0.143 & 0.714 \\
\hline Bois Madame & 8 & & & & & & & & & 0.375 & 0.250 & 0.375 \\
\hline Hastière M & 1 & & & & & & & & & 1.000 & & \\
\hline Sclaigneaux & 5 & Groove & & & & & & & & 0.200 & 0.600 & 0.200 \\
\hline Maurenne & 3 & Pattern & & & & & & & & 0.667 & 0.000 & 0.333 \\
\hline Bois Madame & 2 & & & & & & & & & 0.500 & & 0.500 \\
\hline Hastière M & 4 & & & & & & & 0.750 & 0.250 & & & \\
\hline Sclaigneaux & 11 & Cusp & & & & & 0.091 & 0.727 & 0.182 & & & \\
\hline Maurenne & 12 & Number & & & & & 0.333 & 0.583 & 0.083 & & & \\
\hline Bois Madame & 9 & & & & & & & 0.778 & 0.222 & & & \\
\hline Hastière M & 5 & & & & & & 0.600 & 0.400 & & & & \\
\hline Trou Garçon & 1 & Cusp & & & & & 1.000 & & & & & \\
\hline Sclaigneaux & 12 & Number & & & & & 0.750 & 0.250 & & & & \\
\hline Maurenne & 8 & $\left(\mathrm{M}_{2}\right)$ & & & & & 1.000 & & & & & \\
\hline Bois Madame & 7 & & & & & & 0.714 & 0.286 & & & & \\
\hline Hastière M & 1 & & & & & & 1.000 & & & & & \\
\hline Sclaigneaux & 7 & Cusp & & & & & 0.429 & 0.429 & 0.143 & & & \\
\hline Maurenne & 3 & Number & & & & & 1.000 & & & & & \\
\hline Bois Madame & 2 & & & & & & 0.500 & 0.500 & & & & \\
\hline Hastière M & 5 & & 1.000 & & & & & & & & & \\
\hline Trou Garçon & 1 & Mid-Trigonid & 1.000 & & & & & & & & & \\
\hline Sclaigneaux & 12 & Crest & 0.917 & 0.083 & & & & & & & & \\
\hline Maurenne & 7 & $\left(\mathrm{M}_{2}\right)$ & 0.857 & 0.143 & & & & & & & & \\
\hline Bois Madame & 5 & & 1.000 & & & & & & & & & \\
\hline Hastière M & 1 & & 1.000 & & & & & & & & & \\
\hline Sclaigneaux & 9 & Mid-Trigonid & 0.889 & 0.111 & & & & & & & & \\
\hline Maurenne & 3 & Crest & 1.000 & & & & & & & & & \\
\hline Bois Madame & 1 & & 1.000 & & & & & & & & & \\
\hline Hastière M & 5 & & 0.400 & 0.600 & & & & & & & & \\
\hline Trou Garçon & 1 & & 1.000 & & & & & & & & & \\
\hline Sclaigneaux & 10 & Protostylid & & 1.000 & & & & & & & & \\
\hline Maurenne & 13 & & 0.538 & 0.462 & & & & & & & & \\
\hline Bois Madame & 7 & & 0.143 & 0.857 & & & & & & & & \\
\hline Hastière M & 4 & & 0.500 & 0.500 & & & & & & & & \\
\hline Trou Garçon & 1 & & & & & 1.000 & & & & & & \\
\hline Sclaigneaux & 9 & Protostylid & 0.222 & 0.778 & & & & & & & & \\
\hline Maurenne & 8 & & 0.250 & 0.750 & & & & & & & & \\
\hline Bois Madame & 5 & & 0.400 & 0.600 & & & & & & & & \\
\hline Hastière M & 1 & & 1.000 & & & & & & & & & \\
\hline Sclaigneaux & 7 & Protostylid & 0.429 & 0.571 & & & & & & & & \\
\hline Maurenne & 2 & $\left(\mathrm{M}_{3}\right)$ & 0.500 & & & & & & 0.500 & & & \\
\hline Bois Madame & 1 & & 1.000 & & & & & & & & & \\
\hline Hastière M & 2 & & & & & 0.500 & 0.400 & & & & & \\
\hline Sclaigneaux & 11 & Hypoconulid & 0.091 & 0.091 & 0.182 & 0.091 & 0.091 & 0.455 & & & & \\
\hline Maurenne & 13 & $\left(\mathrm{M}_{1}\right)$ & 0.308 & & & 0.308 & 0.154 & 0.231 & & & & \\
\hline Bois Madame & 9 & & & & & 0.333 & 0.222 & 0.444 & & & & \\
\hline Hastière M & 5 & & 0.600 & 0.200 & & 0.200 & & & & & & \\
\hline Trou Garçon & 1 & & 1.000 & & & & & & & & & \\
\hline Sclaigneaux & 13 & Hypoconulid & 0.769 & & & 0.154 & 0.077 & & & & & \\
\hline Maurenne & 8 & & 1.000 & & & & & & & & & \\
\hline Bois Madame & 7 & & 0.714 & 0.143 & & & & 0.143 & & & & \\
\hline Hastière M & 1 & & 1.000 & & & & & & & & & \\
\hline Sclaigneaux & 7 & Hypoconulid & 0.429 & 0.286 & & & 0.143 & 0.143 & & & & \\
\hline Maurenne & 3 & $\left(\mathrm{M}_{3}\right)$ & 1.000 & & & & & & & & & \\
\hline Bois Madame & 2 & & 0.500 & & & & 0.500 & & & & & \\
\hline Hastière M & 4 & & 0.750 & & 0.250 & & & & & & & \\
\hline Sclaigneaux & 11 & Entoconulid & 0.818 & 0.182 & & & & & & & & \\
\hline Maurenne & 12 & $\left(\mathrm{M}_{1}\right)$ & 0.917 & & 0.083 & & & & & & & \\
\hline Bois Madame & 9 & & 0.778 & & 0.111 & 0.111 & & & & & & \\
\hline Hastière M & 1 & & 1.000 & & & & & & & & & \\
\hline Sclaigneaux & 7 & Entoconulid & 0.857 & & 0.143 & & & & & & & \\
\hline Maurenne & 3 & $\left(\mathrm{M}_{3}\right)$ & 1.000 & & & & & & & & & \\
\hline Bois Madame & 2 & & 1.000 & & & & & & & & & \\
\hline
\end{tabular}


prevalent on $\mathrm{M}_{2}$ and the most frequent expression on $\mathrm{M}_{3}$ (see Table 4). All three groove patterns are present at Bois Madame for $\mathrm{M}_{2}$ as they are at Sclaigneaux and Maurenne. However, only at Sclaigneaux are the three groove patterns present on $\mathrm{M}_{3}$.

\section{Cusp number}

Only five or six cusps are observed on $\mathrm{M}_{1}$ at the early/late Neolithic cave burial of Hastière M and the final/late site of Bois Madame, whereas Sclaigneaux and Maurenne both present 4-6 cusps. However, the predominant number is five cusps across the cave burials (see Table 4).

This pattern differs for $\mathrm{M}_{2}$ in which four cusps is the most frequently observed. For the individuals from Maurenne $(n=8)$ and the individual from Trou Garçon, this is the only pattern observed for $\mathrm{M}_{2}$. In comparison, there are some $\mathrm{M}_{2}$ from Hastière $M$, Sclaigneaux and Bois Madame that present five cusps (see Table 4).

For $\mathrm{M}_{3}$, there are primarily four cusps, with the exception of Maurenne and Sclaigneaux in which the expression of four and five cusps are equally represented (Table 4). Furthermore, at Sclaigneaux, more variation is observed for $\mathrm{M}_{3}$ cusp number which includes the expression of four, five and six cusps.

\section{Mid-trigonid crest}

The mid-trigonid crest is eliminated for $\mathrm{M}_{1}$ since no presence was recorded across sites for this molar. The mid-trigonid crest is also largely absent on $\mathrm{M}_{2}$ and $\mathrm{M}_{3}$ at these Neolithic cave burials. One exception is at Sclaigneaux where it is present, although rarely, on both $\mathrm{M}_{2}$ and $\mathrm{M}_{3}$. The only other site where a mid-trigonid crest is observable is at Maurenne and only the $\mathrm{M}_{2}$ of Maurenne 18 (see Table 4).

\section{Protostylid}

A buccal pit (score of 1 ) is common at these Neolithic cave deposits and across the mandibular molar row (Figure 5). At Sclaigneaux, the buccal pit is found on all individuals examined $(n=10)$. Similarly, a buccal pit is more often present than absent on $\mathrm{M}_{1}$ at Hastière $\mathrm{M}$ and Bois Madame. In contrast, at Maurenne a buccal pit on $\mathrm{M}_{1}$ is more often absent than present; this feature is also absent in the single individual from Trou Garçon (Table 4).

On $\mathrm{M}_{2}$, a buccal pit is visible at all sites and is more often expressed than not, particularly at Sclaigneaux and Maurenne (see Table 4). One ex- ception is Trou Garçon 3, where a protostylid is scored as a 3.

Any variation of the protostylid is less frequently exhibited on $\mathrm{M}_{3}$ than on the other molars. At Sclaigneaux, it is expressed as a buccal pit across the molar row. A much stronger expression of a protostylid is evidenced on one individual, Maurenne 15, where it is scored as a 6.

Hypoconulid (Cusp 5)

For $\mathrm{M}_{1}$, Hastière $\mathrm{M}$ exhibits a moderate to large hypoconulid, expressed at scores of 3 and 4 . Sclaigneaux presents the greatest degree of variation in the expression of the hypoconulid, ranging across the full spectrum of scores from $0-5$, although the majority of individuals from this site are skewed towards the higher end of the scoring spectrum. This variation is similar at Bois Madame and Maurenne where the scores range from 0-5. However, most individuals from Bois Madame exhibit a larger hypoconulid with a correspondingly higher score and nearly a third of the individuals from Maurenne lack a cusp 5 entirely (see Table 4).

For $\mathrm{M}_{2}$, the hypoconulid is more often absent than present across cave burials, and at Maurenne and Trou Garçon it is absent altogether. When it is expressed, the final/late Neolithic caves of Sclaigneaux and Bois Madame both show greater variation and the presence of a larger cusp 5 . For example, when the hypoconulid is expressed at Hastière $M$, it ranges in score from 1-3. At the final/late Neolithic sites of Sclaigneaux and Bois Madame, a larger hypoconulid is evident, reflected in one individual from each site scoring a 4 and 5, respectively (see Table 4).

Like $\mathrm{M}_{2}$, the variation in $\mathrm{M}_{3}$ is more variable than observed in $\mathrm{M}_{1}$, especially for the final/late Neolithic cave burials. The hypoconulid is completely absent in the one individual from Hastière $\mathrm{M}$ and the three individuals from Maurenne. In contrast, at the final/late Neolithic cave of Sclaigneaux, the greatest extent of variation is observed, with scores ranging from a low of 1 to a high of 5. Bois Madame has similar variability of expression of the hypoconulid, with scores extending from $0-4$.

\section{Entoconulid (Cusp 6)}

An entoconulid is expressed on $\mathrm{M}_{1}$ across the cave burials but at low frequencies. However, its expression varies. The most common expression of the entoconulid, or cusp 6, is a score of 2 , as observed at Hastière M, Maurenne and Bois Mad- 
ame. Sclaigneaux presents an entoconulid with a score of 1 . At the other extreme is Bois Madame in which a larger entoconulid is scored as a 3 . Thus, the final/late Neolithic caves of Sclaigneaux and Bois Madame are distinct in the expression of cusp 6 as compared to the other sites.

The entoconulid on $\mathrm{M}_{2}$ was eliminated from the results because it is not observed across the sites. For $\mathrm{M}_{3}$, the entoconulid is entirely absent with the exception of Sclaigneaux. This final/late Neolithic cave burial presents one individual (Sclaigneaux 19) out of seven with an entoconulid on $M_{3}$ that is scored as a 2.

\section{Metaconulid (Cusp 7)}

Frequencies for the metaconulid (Cusp 7) are excluded since only a single tooth fully expressed this trait in the available Neolithic sample, the left $\mathrm{M}_{1}$ of Boise Madame BM Md 13 (Figure 6).

\section{Discussion}

Based on an earlier study of deciduous molar mor-

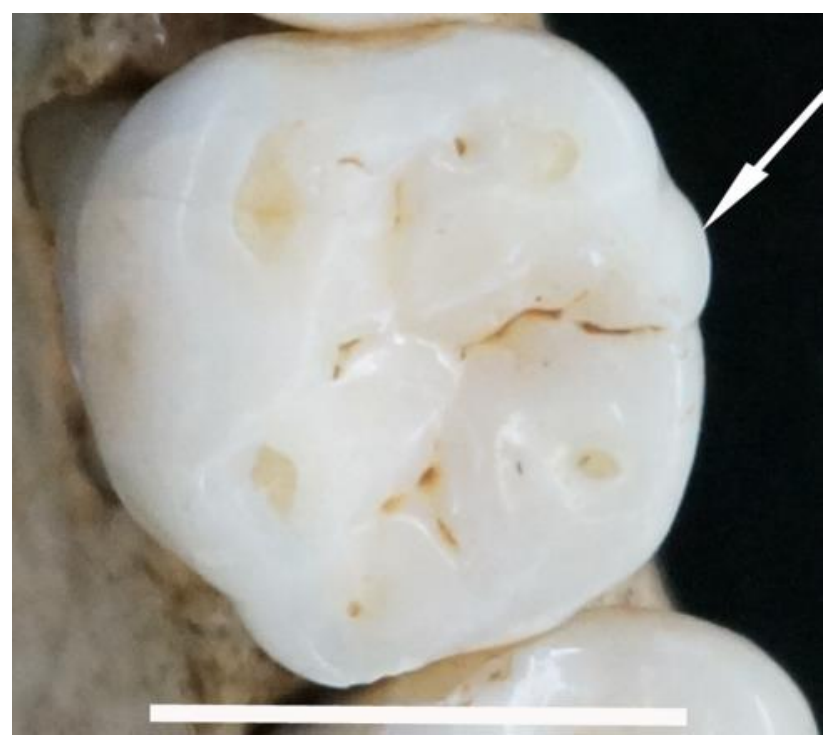

Figure 6. Left mandibular fragment of BM Md 13, presents the only fully expressed metaconulid (Cusp 7) observed (ASUDAS score $=2$ ), demarcated by the white arrow on $\mathrm{M}_{1}$; scale bar $=1 \mathrm{~cm}$.

phology (Williams et al., 2018), it was predicted that the early/late Neolithic cave burial of Hastière $\mathrm{M}$ would be distinctive and should differ from the final/late sites of Sclaigneaux and Bois Madame. Although this prediction was confirmed for some traits, the deciduous molar morphology of Hastière $\mathrm{M}$ is more distinctive compared to the permanent molars. The observation that deciduous molars are better at identifying relatedness (Paul and Stojanowski, 2017) may also apply to these Neolithic cave burials.

It was also anticipated that Sclaigneauxsituated about $35 \mathrm{~km}$ from the Hastière rockshelter-would be distinct if differences in morphology can be explained by geographic distance (Figure 1). Sclaigneaux does differ from the other cave burials in some respects, for example, showing the $Y$ groove pattern for $\mathrm{M}^{2}$. However, like the other final/late Neolithic site of Bois Madame, Sclaigneaux is quite variable in the expression of traits. These findings suggest variability is more pronounced in the final/late than the early/late Neolithic. The final/late Neolithic sites exhibit greater variation in the expression of traits, particularly the hypoconulid, protostylid, parastyle and Carabelli's trait across the molar row. However, the sample sizes are also substantially larger at the final/late Neolithic sites. This is particularly true of Sclaigneaux. It is unknown the extent to which the uneven sample sizes influenced the results.

It was expected that the two early/late Neolithic cave burials of Hastière M and Trou Garçon should resemble one another as they are similar chronologically and geographically. Yet there is no convincing evidence that they are similar. In fact, it appears that Trou Garçon resembles the final/late Neolithic sites of Bois Madame and secondarily Maurenne more than these individuals resemble Hastière M. Trou Garçon has a greater number of whole crania available but is represented by a smaller number of individuals compared to the other sites (Table 2). The limited sample size for Trou Garçon precludes definitive statements on its relationship to the other cave burials. However, Trou Garçon individuals are at times extreme in the expression of traits which separates this site from the others, such as a large protostylid on $\mathrm{M}_{2}$ in Trou Garçon 3. Meanwhile, Hastière $M$ is an outlier in other ways, such as the pronounced metaconule on $\mathrm{M}^{3}$ in Hastière M 29.

The prediction that Maurenne would resemble the final/late Neolithic sites of Sclaigneaux and Bois Madame more than Hastière $M$ was largely confirmed by the results. For this reason, it is more likely that the individuals buried at Maurenne are primarily associated with the three final/late Neolithic radiocarbon dates. The single Middle Neolithic date obtained from Maurenne may be an exception. Supporting this assertion is the observation of similarities between Maurenne and Bois Madame. Three of the dates for the former and the two dates for the latter overlap one another and the two burial chambers are about $10 \mathrm{~km}$ from one another suggesting, perhaps, closer contact existed between these two groups than between the earlier 
and the more geographically distant individuals living close to Sclaigneaux cave.

There are also similarities between the caves, such as the large prevalence of a protostylid and Carabelli's trait, and the near absence of a metaconulid. There are most frequently five cusps on $\mathrm{M}_{1}$ but often four on $\mathrm{M}_{2}$ and $\mathrm{M}_{3}$. The lack of discrete differences in these Belgian Neolithic caves is supported by archaeological evidence that suggests common lifeways, an undifferentiated economy and phenotypic homogeneity. Carbon and nitrogen isotopes imply similarities in diet across the Late Neolithic period in which terrestrial resources were relied upon more than aquatic ones (Semal et al., 1999). The dental microwear of several Late Neolithic caves suggests similarities in diet which comprised a large amount of vegetable fiber (Garcia-Martín, 2000), but fish may have also been consumed (Toussaint et al., 2001). Stature regression formulae from available Neolithic long bones and the first metatarsal indicate that most of the individuals were of short stature. It is also possible that the majority of the long bones come from a single sex (female) as the sample lacks a bimodal distribution of values typical of recent Belgians of both sexes (Orban et al., 2000).

\section{Comparison with other prehistoric burials}

A number of studies have been conducted using dental morphology as a proxy for affinity at Neolithic and other prehistoric sites. Studies of kinship within and across burials and cemeteries rely on phenotypic similarity as a proxy for genetic relationships and rare traits are often utilized to identify familial relations (Bentley, 1991; Howell and Kintigh, 1996; Alt et al., 1997; Jacobi, 1997; Corruccini and Shimada, 2002; Stojanowski \& Schillaci, 2006; Pilloud, 2009; Lukacs \& Pal, 2013). Familial, and possibly sibling relations among a triple burial at Dolní Věstonice from the Upper Paleolithic of the Czech Republic were evidenced by a sharing of groove pattern, number of cusps, accessory cusps and the presence of an entoconulid and parastyle for at least two of the three individual for each trait (Alt et al., 1997). The Neolithic cave burials of Belgium probably do not represent individuals from the same family as noted at Dolní Věstonice. In fact, it appears that there is a greater degree of variation within the Belgian Meuse Neolithic burials than between them.

Dental traits of early Neolithic Mediterranean sites The dental morphology of several burial sites in the Mediterranean region have been explored. For example, at early Neolithic Çatalhöyük in Turkey, the protostylid, Carabelli's cusp, groove pattern, the hypoconulid, entoconulid, hypocone and deflecting wrinkle are significantly different from expected (Pilloud, 2009; Pilloud and Larsen, 2011). Iberian and Italian Neolithic burials differ in Carabelli's trait and the protostylid among other dental traits (López-Onaindia \& Subirà, 2017). The protostylid on $\mathrm{M}_{2}$ and $\mathrm{M}_{3}$, the hypoconulid of $\mathrm{M}_{1}$ and $\mathrm{M}_{2}$, and the entoconulid on $\mathrm{M}_{2}$ and to a lesser extent, groove pattern and cusp number on $\mathrm{M}_{2}$, are suggested to be the most informative in separating Iberian from Italian Neolithic burials (LópezOnaindia et al., 2018). The Neolithic cave burials of Belgium exhibit substantial variation in all of these traits, particularly the size of the hypocone and the expression of Carabelli's trait, and remarkable uniformity in the presence of a protostylid.

\section{Dental morphology of Late Neolithic cave burials of Eurasia}

Numerous Late Neolithic collective burials exist across Eurasia, such as the Late Neolithic-

Chalcolithic collective tombs of Catalonia in which natural crevices and recesses include adults of both sexes and all ages with few grave goods (LópezOnaindia et al., 2018). However, the dental morphology of only a few Late Neolithic sites have been studied in detail. An important exception concerns those surrounding Lake Baikal, Siberia where an increasingly greater percentage of Carabelli's trait occurs during the Neolithic period (Waters-Rist et al., 2016). Compared to the Late Neolithic collective burials of Belgium, a lower expression of this trait is observed and only at Bois Madame and Sclaigneaux is a large Carabelli's cusp evident (Table 3). Hastiére M and Bois Madame have higher frequencies of a $\mathrm{Y}$ groove pattern on $\mathrm{M}_{2}$ (0.250) compared to those observed in Late Neolithic Siberians (0.140) (Waters-Rist et al., 2016), although Sclaigneaux has a much lower value of 0.067 (see Table 4). For cusp number of $\mathrm{M}_{2}, 71.4 \%$ of the Siberian Late Neolithic peoples of Lake Baikal exhibit $5+$ cusps whereas the Late Neolithic burials from Belgium can be characterized as expressing fewer cusps on the second mandibular molar. In fact, mostly only four cusps are observed on $\mathrm{M}_{2}$. However, Hastiére $\mathrm{M}$, and to a lesser extent, Bois Madame and Sclaigneaux, show some expression of five cusps on $\mathrm{M}_{2}$, ranging from 0.400 to 0.250 (see Table 4). Expression of a protostylid on $\mathrm{M}_{1}$ is present in half of Late Neolithic peoples of Lake Baikal, Siberia (Waters-Rist et al., 2016), whereas for this temporal period in the Meuse Riv- 
er basin of Belgium is it present more often than it is absent, and at Sclaigneaux it is observed in $100 \%$ of individuals $(n=10)$ (Table 4$)$. More than a quarter of individuals $(27 \%)$ of the Late Neolithic of Siberia exhibit an entoconulid (Cusp 6) on $\mathrm{M}_{1}$ (Waters-Rist et al., 2016). Comparable frequencies for the collective burials of Late Neolithic Belgium for this trait exist at Hastiére $M$ and to a lesser extent, Bois Madame (Table 4). Unlike their counterparts to the east who exhibit a low occurrence of a metaconulid (Cusp 7) on $\mathrm{M}_{1}$ at $6.5 \%$ (Waters-Rist et al., 2016), at the Late Neolithic caves of Belgium, it is nearly absent with the exception of BM Md 13 from Bois Madame (Figure 6).

\section{Conclusions}

The five well-studied collective burials examined are somewhat discrete in terms of chronology based on radiocarbon dates. Although only limited samples are available for each cave burial, it appears that our predictions were confirmed.

Hastière $\mathrm{M}$ is only partly distinct from the other cave deposits in the expression of traits, corroborating an analysis of deciduous molar morphology from the Late Neolithic caves of the Belgian Meuse basin (Williams et al., 2018). The final/late collective burials of Sclaigneaux and Bois Madame exhibit a greater range of expression of the hypoconulid, entoconulid, protostylid, Carabelli's cusp, metacone and metaconulid. Although differences between the final/late Neolithic cave burials of Sclaigneaux and Bois Madame and the others from Hastière rockshelter are evidenced by dental morphology, these sites likely represent ephemeral communities that experienced only limited continuity over time and were perhaps bounded as a function of distance, and to a lesser degree, by chronology. Alternatively, this lack of partitioning of discrete dental traits per burial location may signal that internment was not strictly kin-based as is observed at Neolithic Çatalhöyük (Pilloud \& Larsen, 2011), though larger sample sizes to conduct statistical analyses would be necessary for an investigation into potential kin relations based on dental morphology. In this study, the very low frequencies of a metaconulid and the mid-trigonal crest characterize the burials. Furthermore, the expression of Carabelli's cusp on $\mathrm{M}^{1}$ and $\mathrm{M}^{2}$ joins Sclaigneaux and Bois Madame and secondarily Hastiére $M$ and Trou Garçon. The greater degree of variation observed for the final/late Neolithic cave burials of Sclaigneaux and Bois Madame may have been the result of a slow but steady influx of peoples, perhaps along waterways, from other loca- tions as a prelude to the population restructuring that occurred concomitantly with the onset of the Bronze Age. This seems to be the case at other locations in Eurasia (Subirà et al., 2014; Waters-Rist et al., 2016; López-Onaindia et al., 2018).

\section{Acknowledgments}

Permission to examine these Neolithic remains in Belgium was kindly provided by Patrick Semal, Chief of the Scientific Heritage Service, Royal Belgian Institute of Natural Sciences. Many thanks to William Anderson and Laura Aday for assisting in the creation of the epoxy resin dental casts. At the Royal Belgian Institute of Natural Sciences, we thank Caroline Polet for generously assisting with the Neolithic collections, and Laurence Cammaert who skillfully created the topographical map of Belgium featured in Figure 1, which we use with permission. We thank Marin Pilloud and the anonymous reviewers for valuable comments that significantly improved the manuscript. Support for this research was provided by Fulbright-Belgium and the Commission for Educational Exchange between the USA, Belgium, and Luxembourg.

\section{REFERENCES}

Alt, K. W., Pichler, S., Vach, W., Klima, B., Vlček, E. \& Sedlmeier, J. (1997). Twenty-five thousandyear-old triple burial from Dolní Věstonice: an Ice-Age family? American Journal of Physical Anthropology, 102, 123-131.

Bailey, S. E. (2008). Inter- and intra-specific variation in Pan tooth crown morphology: implications for Neandertal taxonomy. In J. D. Irish \& G. C. Nelson (Eds.), Technique and application in dental anthropology (pp. 293-316). Cambridge, U.K.: Cambridge University Press.

Bentley, G. R. (1991). A bioarchaeological reconstruction of the social and kinship systems at early Bronze Age Bab Edh-Dhra', Jordan. In S. A. Gregg (Ed.), Between bands and states (pp. 534). Carbondale: Center for Archaeological Investigations, Southern Illinois University at Carbondale Occasional Paper No.9.

Bronk-Ramsey, C., Higham, T. F. G., Owen, D. C., Pike, W. G. \& Hedges, R. E. M. (2002). Radiocarbon dates from the Oxford AMS system: datelist 31. Archaeometry, 44(3) Supplement 1, 1-149.

Corruccini, R. S. \& Shimada, I. (2002). Dental relatedness corresponding to mortuary patterning at Huaca Loro, Peru. American Journal of Physical Anthropology, 117, 118-121.

De Paepe, M. (2007). Studie van de laat- 
neolithische menselijke resten uit een collectief graf te Sclaigneaux (provincie Namen, B.). MA thesis, Universiteit Gent.

De Paepe, M. \& Polet, C. (2007). 'Numerous and tall': A revision of the Late Neolithic human remains found in a collective burial site at Claigneaux (prov. Namr), Belgium. Notæ Præhistoricæ, 27, 163-168.

Dumbruch, I. (2003). Edute du site de l'abri-sousroche du "Bois-Madame", Néolithique, à Arbre, dans la vallée du Burnot (Province de Namur). Etude anthropologique et archéologique, Volume I et II. MA thesis, Université Libre de Bruxelles.

Dumbruch, I. (2007). Le Site de l'Abri-sous-Roche du "Bois-Madame" à Arbre (Province de Namur, Belgique). Archæologia Mosellana, 7, 609612.

García-Martín, C. (2000). Reconstitution du régime alimentaire par l'étude des micro-traces d'usure dentaire. Master Européen en Anthropologie, Université Libre de Bruxelles.

Hardin, A. M. \& Legge, S. S. (2013). Geographic variation in nonmetric dental traits of the deciduous molars of Pan and Gorilla. International Journal of Primatology, 34, 1000-1019.

Howell, T. L. \& Kintigh, K. W. (1996). Archaeological identification of kin groups using mortuary and biological data: an example from the American Southwest. American Antiquity, 61, 537-554.

Irish, J. D. (2006). Who were the ancient Egyptians? Dental affinities among Neolithic through postdynastic peoples. American Journal of Physical Anthropology, 22, 529-543.

Jacobi, K. P. (1997). Dental genetic structuring of a colonial Maya cemetery, Tipu, Belize. In S. L. Whittington \& D. M. Reed (Eds.), Bones of the Maya: studies of ancient skeletons (pp. 138-153). Washington: Smithsonian Institution Press.

López-Onaindia, D. \& Subirà, M. E. (2017). Prehistoric funerary complexity in northern Iberia studied using dental morphology. Homo: Journal of Comparative Human Biology, 68, 122-133.

López-Onaindia, D., Coca, M., Gibaja, J. F. \& Subirà, M. E. (2018). Biological differences related to cultural variability during the Neolithic in a micro-geographical area of the Iberian Peninsula. Archaeological and Anthropological Sciences, 10, 1957-1969.

Lukacs, J. R. \& Pal, J. N. (2013). Dental morphology of early Holocene foragers of North India: non -metric trait frequencies and biological affinities. Homo: Journal of Comparative Human Biolo$g y, 64,411-436$.
McHugh, M. L. (2012). Interrater reliability: the kappa statistic. Biochemica Medica 22, 276-282.

Orban, R., Polet, C., Semal, P. \& Leguebe, A. (2000). La stature des Néolithiques mosans. Bulletin de l'Institut Royal des Sciences Naturelles de Belgique-Sciences de la Terre, 70, 207-222.

Pilloud, M. A. (2009). Community structure at Neolithic Çatalhöyük: biological distance analysis of household, neighborhood, and settlement. Ph.D. dissertation. The Ohio State University.

Pilloud, M. A. \& Larsen, C. S. (2011). "Official" and "practical" kin: inferring social and community structure from dental phenotype at Neolithic Çatalhöyük, Turkey. American Journal of Physical Anthropology, 145, 519-530.

Polet, C. (2011). Les squelettes néolithiques découverts dans les grottes du basin mosan. In N. Cauwe, A. Hauzeur, I. Jadin, C. Polet \& B. Vanmontfort (Eds.), 5200-2000 av. J.- C. Premiers Agriculteurs en Belgique (pp. 85-94). Éditions du Cedarc.

Scott, G. R. \& Turner, C. G., II (1997). The anthropology of modern human teeth: dental morphology and its variation in recent human populations. Cambridge, U.K.: Cambridge University Press.

Scott, G. R., Turner, C. G., II, Townsend, G. C. \& Martinón-Torres, M. (2018). The anthropology of modern human teeth: dental morphology and its variation in recent and fossil Homo sapiens, $2^{\text {nd }}$ ed. Cambridge, U.K.: Cambridge University Press.

Semal, P., García Martín, C., Polet, C. \& Richards, M. P. (1999). Considération sur l'alimentation des Néolithiques du Bassin mosan: usures dentaires et analyses isotopiques du collagène osseux. Notæ Præhistoricæ, 19, 127-135.

Smith, B. H. (1984). Patterns of molar wear in hunter-gatherers and agriculturalists. American Journal of Physical Anthropology, 63, 39-56.

Stojanowski, C. M., \& Schillaci, M. A. (2006). Phenotypic approaches for understanding patterns of intracemetery biological variation. Yearbook of Physical Anthropology, 49, 49-88.

Subirà, M. E., López-Onaindia, D. \& Yll, R. (2014). Cultural changes in funeral rites during the Neolithic in the northeast of the Iberian Peninsula? The Cave of Pantà de Foix (Barcelona). International Journal of Osteoarchaeology, 26, 104 $-113$.

Toussaint, M. (2007). Les sépultures Néolithiques du basin mosan Wallon et leurs relations avec les bassins de la Seine et du Rhin. Archaeologia Mosellana, 7, 507-549. 
Toussaint, M., Orban, R., Polet, C., Semal, P., Bocherens, H., Masy, P. \& García Martín, C. (2001). Apports récents sur l'anthropologie des Mésolithiques et des Néolithiques mosans. Anthropologica et Præhistorica, 112, 91105.

Toussaint, M., Lacroix, P., Lambermont, S., Lemarie, J. -F., Bruzzese, L. \& Beaujean, J. -F. (2003). La sépulture d'enfant néolithique des nouveaux réseaux du Trou du Moulin, à Goyet (Gesves, province de Namur). Anthropologica et Præhistorica, 116, 179-210.

Turner, C. G., II, Nichol, C. \& Scott, G. R. (1991). Scoring procedures for key morphological traits of the permanent dentition: the Arizona State University dental anthropology system. In M. A. Kelley \& C. S. Larsen (Eds.), Advances in dental anthropology (pp. 13-31). New York: Wiley-Liss.

Vanderveken, S. (1997). Etude anthropologique des sépultures néolithiques de Maurenne et Hastière (province de Namur). MA thesis, Université Libre de Bruxelles.

Vanderveken, S. (2007). Les ossements humans néolithiques de Maurenne et Hastière (Province de Namur). Notæ Præhistoricæ, 17, 177-184.

Waters-Rist, A., Bazaliiskii, V. I., Goriunova, O. I., Weber, A. W. \& Katzenberg, M. A. (2016). Evaluating the biological discontinuity hypothesis of Cis-Baikal Early versus Late Neolithic-Early Bronze Age populations using dental nonmetric traits. Quaternary Internation$a l, 405,122-133$.

Williams, F. L., George, R. L. \& Polet, C. (2018). Deciduous molar morphology from the Neolithic caves of the Meuse River Basin, Belgium. Dental Anthropology, 31, 18-26. 